\title{
PTS Statement on Virtual Congress 2020
}

Dear members of the Panamerican Trauma Society, due to the COVID-19 pandemic, we have decided together with the Mexican Association of General Surgery with whom this year we will be hosting the congress, that it will be completely virtual. We have decided this due to the fact that there are still travel restrictions and a high number of contacts in the American continent, we firmly believe that social distance measures, the restriction of mass meetings in closed spaces, are effective in ending the number of contacts in the population. We will surely miss face-to face coexistence and socializing with colleagues and friends, but this time, it should be a new experience for everyone-conference attendees, professors, industry, their representatives and family. This pandemic has changed the way of life around the world, education and updates. This situation in one way or another has allowed us to bring knowledge to those who due to time, economy or operating facilities and

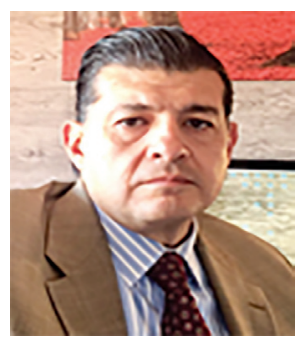
other various reasons, cannot travel, stay and attend the congress.

Finally, the goal of improving trauma care in the Americas is embedded in our mission. Unfortunately, last year due to social and political events in Chile, the congress was suspended, and we did not have the creativity to hold the congress in the same mode that we will do it in this 2020. We never imagined this year that a virus would do so much damage and was going to limit us to meet and be close to others, from others, that the medical community was going to be directly modified with high contagion, disease and death. International relations changed and many borders closed. Videoconferences and virtual seminars brought the distant ones closer and the pandemic distanced the near ones. Now then, let's venture into this new way of learning and exchanging experiences, you will be welcome to the virtual congress of the Panamerican Trauma Society hosted by the Mexican Association of General Surgery next October, that after 34 years of our society, it's the first time that they venture together and merge to reach the community of health professionals in Latin America.

\author{
Dr. Felipe Vega Rivera \\ President (2018-2020) \\ Panamerican Trauma Society
}

\section{Comunicado SPT sobre Congreso Virtual 2020.}

Estimados miembros de la sociedad panamericana de trauma, debido a la pandemia del Covid-19, hemos decidido en conjunto con la Asociación Mexicana de Cirugía General con quien en este ano realizamos el congreso conjuntamente, realizar el congreso totalmente virtual. Esto lo hemos decidido en virtud de que aun existen restricciones de viaje y alto número de contagios en el continente americano, creemos firmemente que las medidas de distancia social, la restricción de reuniones masivas en espacios cerrados es efectivas para terminar con el numero de contagios en la población. Seguramente extrañaremos como siempre la convivencia cara a cara y socializar con colegas y amigos, pero en esta ocasión esto debe ser una nueva experiencia para todos, asistentes al congreso, profesores, industria, sus representantes y familia. Esta pandemia ha cambiado el modo de vida de todo el mundo, la educación y la actualización. Esta situación de alguna u otra forma nos ha permitido acercar el conocimiento a todos aquellos a quienes ya sea por tiempo, economía o facilidades operativas y otras diversas razones no podían viajar, hospedarse y asistir al congreso.

Finalmente, el objetivo de mejorar el cuidado del trauma en las Américas va inmerso en nuestra misión. Lamentablemente el año pasado debido a los acontecimientos sociales y políticos en Chile, por lo que suspendimos el congreso, no tuvimos la creatividad para realizar el congreso de la misma manera que lo realizaremos este 2020, nunca nos imaginamos que este año un virus iba a hacer tanto daño e iba a limitarnos en reunirnos y estar cerca los unos de otros, que la comunidad médica se iba a ver directamente afectada con alto contagio, enfermedad y muerte. Las relaciones internacionales cambiaron y muchas fronteras cerraron. Las videoconferencias y los seminarios virtuales acercaron a los lejanos y la pandemia alejo a los cercanos. Ahora bien, incursionemos en esta nueva manera de aprender e intercambiar experiencias, bienvenidos el congreso virtual de la Sociedad Panamericana de Trauma hospedado por la Asociación Mexicana de Cirugía General este próximo octubre, que después de 34 años de fundada nuestra sociedad es la primera vez que incursionan juntos y se fusionan para llegar a la comunidad de profesionales de la salud de América Latina.

Dr. Felipe Vega Rivera Presidente (2018-2020) Sociedad Panamericana de Trauma 